\title{
The Managerial Decision Styles of Academic Library Directors
}

\section{Terrence F. Mech}

The decision styles of 370 academic library directors are examined using the Decision Style Inventory. Survey results indicate that most directors have an idea rather than an action orientation; with the exception of directors at baccalaureate institutions, they are primarily left-brain dominant. However, there are significant differences in the preferred decision styles among directors at doctoral, comprehensive, baccalaureate, and two-year institutions.

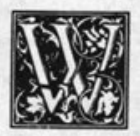

hile the powers of the autocratic library director have been curtailed by the advancement of enlightened principles of participative management, library directors will continue to influence, make, and be responsible for hundreds of decisions. The consequences of some decisions may have long-term ramifications for library personnel and operations. Because library directors are not all alike, an understanding of directors' decision styles and the influence of cognitive preferences on decisions may improve our understanding of library managers and management.

Some directors are results-oriented and impersonal, relying on facts and figures to make decisions; others are sensitive and responsive to the needs and feelings of others and make decisions cognizant of their impact on people. Some directors are planners who rely on careful analysis before making a decision, while others are creative, innovative, and take risks, depending more on intuition than on facts. Although there are no right or wrong decision styles, different styles have their own strengths and weaknesses and some styles are more effective in certain situations and environments than others. ${ }^{1}$ This exploratory study profiles the managerial decision styles of academic library directors and examines the extent to which directors' decision styles vary according to the type of institution.

\section{LITERATURE REVIEW}

Very little is written about librarians' decision-making methods. However, studies concerning librarians' cognitive approaches may shed some light on how librarians make decisions. Research has already established a relationship between cognitive style and decision making. ${ }^{2}$ Cognitive style, a characteristic mode of perceptual and intellectual functioning, is the way individuals perceive and process information. ${ }^{3}$ According to J. Hill, "Cognitive styles are determined by the way individuals take note of their surroundings-how they seek meaning, how they become informed. Are they listeners or are they readers? Are they concerned only with their own viewpoint or are they influenced in decision-making by their families or associates?"4 At an early age, individuals develop preferred ways of perceiving and thinking that serve them well and remain relatively unchanged over their lifetimes. ${ }^{5}$

The field dependence/field independence dimension is an aspect of

Terrence F. Mech is Library Director at King's College, Wilkes-Barre, Pennsylvania 18711. 
cognitive style that has been studied extensively. Field dependence/field independence differentiates individuals according to how they view an object in relation to its surroundings. ${ }^{6}$ Field dependence is the tendency to see an object in context-to have a more integrated approach to perception. Field independence is a tendency to take an analytical approach by separating the object from its context or environment. Field dependent individuals tend to be more aware of social frames of reference, are more sensitive to nonverbal communication, and may appear more warm, tactful, considerate and socially outgoing than field independent individuals. ${ }^{7}$ Because they are less inclined to separate objects from their environments, field dependent individuals prefer more holistic, intuitive approaches to problem solving. ${ }^{8}$

Field independent individuals tend to be more impersonal in working with others. They are better able to work alone and are more interested in theoretical and abstract tasks. ${ }^{9}$ Individuals with high field independence prefer problem-solving methods that emphasize detail and basic relationships. ${ }^{10}$ The social skills of field dependents contrast with the analytical skills of the field independents."

Information science students with undergraduate majors in the arts, sciences, humanities, and history tend to be more field independent. Those with undergraduate degrees in education, the social sciences, and library science, on the other hand, tend to be more field dependent. Students with a preference for reference tend to be field dependent. ${ }^{12}$ Reference librarians' field dependence does not vary by type of institutional affiliation (public,academic, or special), but subject specialists tend to be more field independent. ${ }^{13}$

A study of communication and cognitive style shows that while library science students prefer written rather than verbal forms of communication, they do use and interpret nonverbal language (i. e., body language, vocal intonation) when communicating verbally. These future librarians tend to accept their own view of situations and only rely secondarily on the views of their peers and associates. If communication breaks down, the library science students tend to see others as being at fault for the miscommunication. When they are actively involved in a situation they may hear what they want to hear, or they may appear aloof. ${ }^{14}$

Recent studies use David A. Kolb's learning style theory to explore librarians' cognitive styles. Kolb sees the learning process as a four-stage cycle (concrete experience, reflective observation, abstract conceptualization, and active experimentation) and identifies four different learning styles (converger, diverger, assimilator, and accommodator). An individual's preferences for a cycle in the learning process influences which learning style he or she develops. ${ }^{15}$

\section{Very little is written about librarians' decision-making methods. However, studies concerning librarians' cognitive approaches may shed some light on how librarians make decisions.}

Convergers prefer abstract and active learning and are strong in the practical application of ideas to problem-solving tasks. They tend to have narrow interests, be unemotional, and prefer to deal with things rather than people. Divergers, the opposite of convergers, prefer reflective and concrete learning and approach problems broadly and imaginatively. They tend to have wide interests, to be emotional, and to be people-oriented. Assimilators prefer abstract and reflective learning and are good at inductive reasoning and theory building. They are less interested in people and less concerned with the practical use of theories. Accommodators prefer concrete and active learning and are good at carrying out plans. They are doers and tend to take risks. They tend to solve problems by trial and error, to rely on others for information, and are not strongly analytical. ${ }^{16}$

Using Kolb's learning style theory, Jana Varlejs found librarians more likely to be divergers ( 33.3 percent) and to have weak abstract conceptualization skills. ${ }^{17}$ 
In a larger study, Jin M. Choi discovered that librarians are more likely to be assimilators (38.6 percent), followed by convergers (27.1 percent), divergers (19.3 percent), and accommodators (15 percent). ${ }^{18}$ Unlike Varlejs, Choi's findings suggest librarians have strong abstract conceptualization skills. While women frequently had a more divergent learning style than men, no significant differences were found between men and women librarians or between public and technical services librarians. These and other studies highlight variations in cognitive styles found in professions such as librarianship. Identifying a particular profession with a particular cognitive style is inaccurate and misleading, and fails to recognize the considerable flexibility of professions to accommodate individuals with diverse cognitive styles. ${ }^{19}$

These studies demonstrate that librarians are cognitively diverse, and that particular attributes may be associated with certain cognitive styles. However, larger and more detailed studies are required before the definitive discussion is held. While these previous studies focused on librarians' cognitive styles, the present study examines decision styles, of which cognitive style is only one element. This exploratory study profiles the decisionmaking approaches of academic library directors and examines the extent to which directors' decision styles vary among the different types of institutions.

\section{DECISION STYLE THEORY}

This study uses the Decision Style Inventory, developed by Alan Rowe, to profile the decision styles of academic library directors. Four contextual variables are relevant to decision making: the reaction of the decision maker to the work environment, the people in the organization, the task to be performed, and the personal needs of the decision maker. A decision maker's response to these variables is determined, in part, by the individual's decision style. An individual's approach to decisions is intrinsic to the individual and can be modified, depending on the situ- ational factors and the individual's ability to cope with expectations..$^{20}$

Rowe's theory of decision style combines cognitive complexity with an individual's concerns for tasks or people, in order to create a holistic look at decision styles. An individual's (1) perception and receptivity to stimuli, (2) ability to handle information and to reach meaningful conclusions, (3) intuition or creativity needed to find workable alternatives, and (4) the skills needed to make the decision become reality are all elements of an individual's decision style. ${ }^{21}$

Figure 1 shows the decision style model. The vertical axis represents cognitive complexity and the horizontal axis represents environmental concerns or values. The less cognitively complex individual tends to perceive the environment in terms of few or rigid rules of information processing and has a high need for structure, whereas the individual possessing a high degree of cognitive complexity is able to integrate diverse cues and has a greater tolerance for ambiguity. ${ }^{22}$

The horizontal dimension of the model addresses the environment in which a person finds herself and her response to it. A more focused individual will generally prefer technical or taskoriented environments. On the other hand, an individual with more divergent interests will tend to prefer the more social or people-oriented environment. According to the model, the technically oriented individual is left-brain dominant; i.e., a logical or analytical person. The right half of the model corresponds with those individuals who reason inductively and who think in broad or spatial terms and are gregarious, right-brain dominant. ${ }^{23}$

The four decision styles are directive, analytical, conceptual, and behavioral. The directive style has a low tolerance for ambiguity and is focused on task and technical concerns. Directives emphasize speed and action and thus use limited information and few alternatives. They tend to be aggressive and authoritarian, and focus internally on the organization with short-range and tight controls. While they may be effec- 


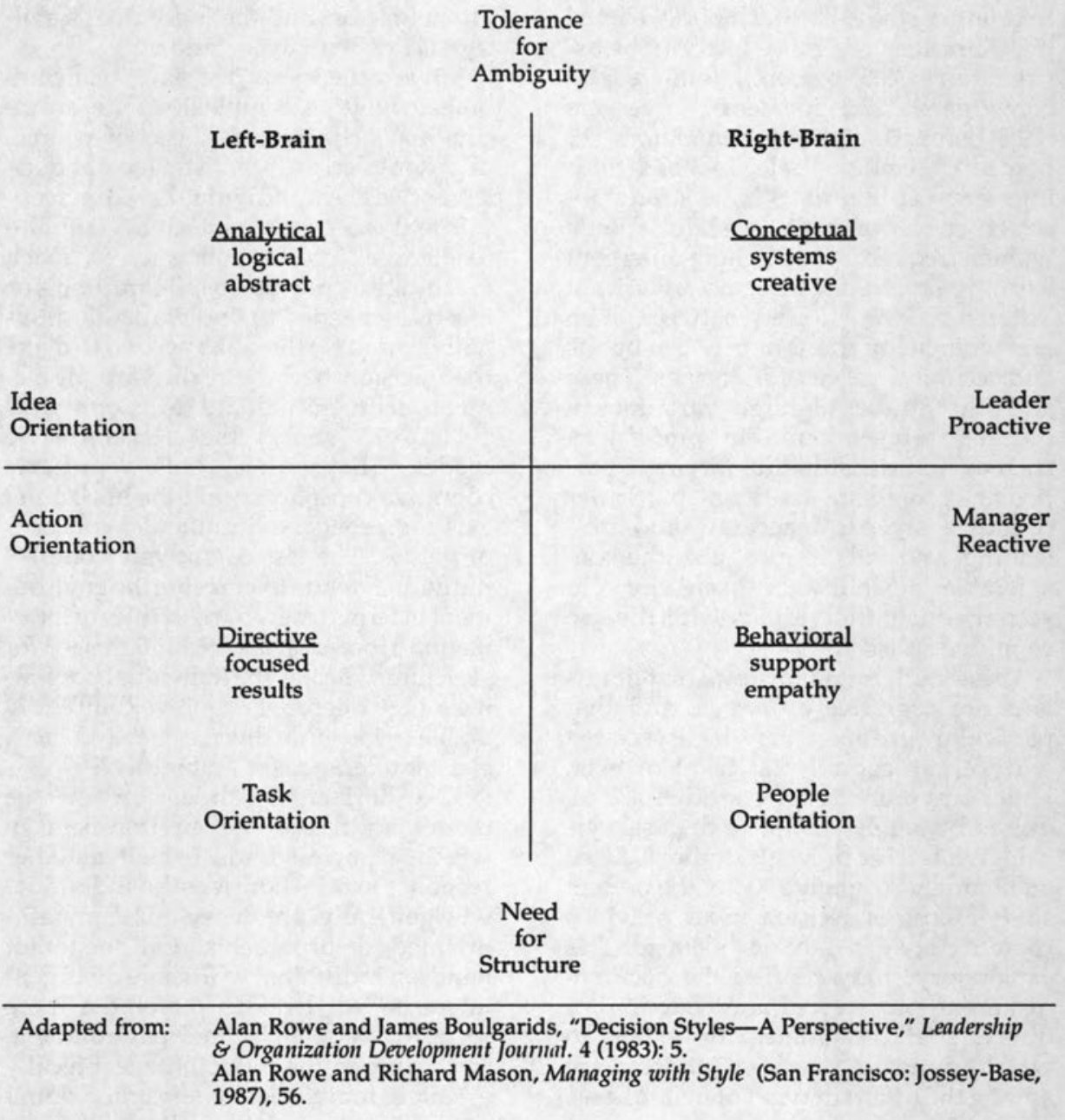

FIGURE 1

Decision Style Model

tive at achieving results, directives have a great need for power and prefer tangible rewards over intrinsic rewards. Directive individuals do well in structured, goal-oriented bureaucracies or other places where power and authority are important. These individuals are criticized for being too rigid, impersonal, simplistic, and autocratic. ${ }^{24}$

The analytical style has a high tolerance for ambiguity and is also oriented toward task and technical concerns. Analytics use considerable information and are very careful in the examination of alternatives. They tend to optimize problem solutions and enjoy challenges. They often reach top positions and are innovative in their solutions to problems. They prefer written reports and look for variety in their work. The analytical and the directive styles are both logical in their approach. Analytic individuals do well in impersonal situations, like planning or solving complex problems. Frequently these peopleare perceived to be dogmatic, overcontrolling, 
impersonal, careful, abstract, and sometimes too slow in performing tasks. ${ }^{25}$

The conceptual style has a high tolerance for ambiguity (considerable complexity) and is interested in people and social concerns. Conceptuals are generally broad and future-oriented thinkers who take a system's perspective. They value quality, prefer openness, and share goals with subordinates. They are very creative and have a deep organizational commitment. They are high achievers who need praise and recognition. They tend to be very independent and refuse to be pressured; they prefer loose control to power and enjoy interacting with others. Conceptual individuals do well in loose, decentralized, or open organizations. These individuals are criticized for being dilettantes, too idealistic, indecisive, imaginative, slow, and difficult to control. ${ }^{26}$

The behavioral style has a low tolerance for ambiguity and is oriented toward people and social concerns. Behaviorals are supportive, good listeners, receptive to suggestions, and communicate easily. They exhibit warmth and will accept loose control. They prefer meetings to reports, and do not use much data in making decisions. Their focus tends to be social with short-range goals. The behavioral and conceptual style people are less logical in their approach than the directive and analytical. Behavioral individuals do well in well-designed, people-oriented, and collegial settings. These people are perceived to be sensitive and perhaps too concerned about others; they tend to have difficulty in making hard decisions and saying no. ${ }^{27}$

The Decision Style Inventory generates four basic scores (directive, analytical, conceptual, and behavioral) and several combination scores (left-brain and right-brain dominance as well as idea and action orientation). According to Rowe and Mason, the Decision Style Inventory is "conceptually and empirically consistent" with the Myers-Brigg Type Indicator. ${ }^{28}$ The twenty-item forced-choice Decision Style Inventory has a test-retest correlation of .7. The split-half coefficients ranged from .5 to
7. ${ }^{29}$ Like the Myers-Brigg Type Indicator the Decision Style Inventory is not intended to be a predictive instrument, but rather a tool for personal discovery.

\section{LEFT/RIGHT-BRAIN DOMINANCE AND IDEA/ACTION ORIENTATIONS}

Brain dominance refers to an individual's tendency to think and act according to the characteristics of one side of the brain rather than the other. $\mathrm{Re}-$ search on the human brain shows that logical and linear functions occur in the left hemisphere, while the holistic, relational functions occur in the right hemisphere. The brain's left side governs the ability to use language, writing, and mathematics, to perform logical deductions and other types of analysis, and to enforce self-discipline. The right side governs visual, spatial, artistic, and intuitive concepts, imagination, and spontaneous play. ${ }^{30}$ Word opposites can be used to distinguish the two modes of brain dominance, left versus right;" explicit versus implicit; verbal versus spatial; argument versus experience; intellectual versus intuitive; and analytical versus gestalt." ${ }^{31}$

Left-brain dominant people process information in a sequential manner and prefer solving problems by breaking them down into parts and approaching them sequentially, using logic. They prefer working with concrete data (rather than nebulous or unstructured data) and like to complete one project before beginning another. These individuals tend to remember names rather than faces: they prefer hierarchical structures, and like their work preplanned and structured. Left-brain oriented individuals like to work alone in a quiet setting, doing tasks that involve analysis, numerical reasoning, problem solving, and achieving results. They like to be in control and focus on the work to be done. Occupations like engineering, accounting, research, law, computer technology, and science attract left-brain-oriented individuals..$^{32}$

Right-brain dominant people enjoy change, flexible schedules, taking on new challenges, and working on several projects at once. Working well under deadlines, many of these individuals 
TABLE 1

CHARACTERISTICS OF DIRECTORS

\begin{tabular}{|c|c|c|c|c|c|c|c|c|}
\hline \multirow{2}{*}{$\begin{array}{l}\text { Characteristics } \\
\text { Public/Private } \\
\text { Gender }\end{array}$} & \multicolumn{2}{|c|}{$\begin{array}{c}\text { Doctoral } \\
(n=80) \\
58 / 22 \\
\end{array}$} & \multicolumn{2}{|c|}{$\begin{array}{c}\text { Comprehensive } \\
(n=104) \\
79 / 25 \\
\end{array}$} & \multicolumn{2}{|c|}{$\begin{array}{c}\text { Baccalaureate } \\
(n=100) \\
21 / 79 \\
\end{array}$} & \multicolumn{2}{|c|}{$\begin{array}{c}\text { Community } \\
(n=86) \\
83 / 3 \\
\end{array}$} \\
\hline & \multirow{3}{*}{\multicolumn{2}{|c|}{$\begin{array}{l}44 \\
36\end{array}$}} & & \multirow{2}{*}{\multicolumn{2}{|c|}{46}} & \\
\hline Male & & & & & & & & \\
\hline \multirow{2}{*}{ Female } & & & \multicolumn{2}{|c|}{39} & \multicolumn{2}{|c|}{53} & \multicolumn{2}{|c|}{42} \\
\hline & $\mathrm{M}$ & SD & $\mathrm{M}$ & SD & $\mathrm{M}$ & SD & $\mathrm{M}$ & SD \\
\hline Age & 50.6 & 6.3 & 50.9 & 9.5 & 49.5 & 11.4 & 49.1 & 9.3 \\
\hline $\begin{array}{l}\text { Years of library } \\
\text { experience }\end{array}$ & 22.8 & $5.5^{\mathrm{a}}$ & 22.8 & $7.2^{\mathrm{ac}}$ & 19.0 & $7.9^{b}$ & 19.8 & $7.4^{\mathrm{d}}$ \\
\hline $\begin{array}{l}\text { Years of } \\
\text { administrative } \\
\text { experience }\end{array}$ & 17.4 & $6.1^{\mathrm{a}}$ & 17.3 & $7.8^{\mathrm{a}}$ & 12.0 & $6.9^{b}$ & 13.5 & $7.6^{\mathrm{b}}$ \\
\hline
\end{tabular}

tend to leave projects or reports until the last minute. They prefer solving problems by looking at the whole for patterns and by using hunches and intuition; they are better at conceptualizing the whole picture rather than attending to all the details involved. These individuals tend to remember faces rather than names, prefer collegial structures, and feel comfortable in fluid and spontaneous situations. Right-brain individuals prefer work that involves people, requires intuition or creativity, and involves visual perspective or broad thinking. They tend to be less focused in their thinking, more open about their emotions, and more influenced by their emotions than leftbrain individuals are. Right-brained people are attracted to careers in the arts, entertainment, teaching, writing, architecture, decorating, counseling, advertising, marketing, sales, and ministry. ${ }^{33}$

Rowe's Decision Style Inventory also measures an individual's preference for ideas or action. Idea-oriented individuals are more concerned with thinking, analysis, perspective, judgment, visualization, innovation, creativity, and new approaches. Action-oriented individuals are concerned with achieving results. They work well with others and find occupations that require direct involvement, achieving results, and interacting with the public. ${ }^{34}$

\section{THE STUDY}

In October 1990, the Decision Style Inventory and a supplementary questionnaire were mailed to 600 library directors - 150 directors from each of the American Association of University Professors' institutional categories: Doctoral (I), Comprehensive (IIA), Baccalaureate (IIB), and Two-year (III). ${ }^{35}$ Usable responses were received from 370 directors, constituting a 62 percent return. During the analysis the institutions were further classified using the Carnegie Classifications. This was particularly useful with baccalaureate institutions, which were separated into selective and less selective colleges.

The chi-square, $t$-test, Pearson product moment correlation coefficient, and analysis of variance programs from the SPSS statistical package were used to analyze the data. The level of statistical significance for this study is .05 .

\section{INDIVIDUAL CHARACTERISTICS}

While 46 percent of the directors are women, women are least likely to be directors at comprehensive institutions (only 38 percent-see table 1 ). Women are more likely to be directors at baccalaureate institutions, particularly among the less selective liberal arts institutions. While there is no significant age difference between men (50.4) and women 
(49.1) directors, there are significant differences between men and women directors in their years of library experience and administrative experience. Males have significantly more years of library and administrative experience. Men directors average 21.9 years of library and 16.9 years of administrative experience compared with women's average of 20.2 years of library and 13.1 years of administrative experience.

\section{The liberal arts and people-centered humanities influence appears to be something selective liberal arts colleges look for in their directors, perhaps to preserve their institutional uniqueness.}

When these characteristics are analyzed by institutional type, an analysis of variance reveals significant differences in both the years of library experience and the years of administrative experience among the directors (see table 1). Further analysis (Scheffe's test) reveals that baccalaureate directors have less library experience than doctoral and comprehensive directors. Among the baccalaureate directors, those at the less selective liberal arts colleges have less library (17.5 years) and administrative (10.5 years) experience than directors at the more selective liberal arts colleges (22.8 years library and 15.5 years administrative experience). Community college directors have less library experience than comprehensive directors. Subsequently, baccalaureate and community college directors average less administrative experience than doctoral and comprehensive directors. There are no significant differences between directors at private and publicsponsored institutions with regard to age and years of library or administrative experience.

In addition to age, gender, and years of library and administrative experience, directors' undergraduate majors were tabulated also. Sixty-five percent of the directors majored in the humanities or history, while 23 percent majored in the social sciences, education, or library science as undergraduates. However, based on their undergraduate majors, directors do not significantly prefer one type of institution, decision style, or orientation over another.

\section{DECISION STYLE PROFILE}

Table 2 presents information on directors' decision styles and orientations. Scores within the very dominant category mean a particular style is used almost exclusively in most situations. Scores within the dominant range indicate a style is used frequently. The backup category reveals which styles are used when the occasion demands it. Scores within the least preferred category indicate a style is seldom used.

When the categories of very dominant and dominant are combined, the behavioral decision style is the predominate decision mode among comprehensive ( 38 percent), baccalaureate (53 percent), and community college (50 percent) directors. For comprehensive directors ( 36 percent), the directive is the second most popular style. Among baccalaureate directors (24 percent), conceptual is the next most preferred approach. The analytical decision style is the second most frequent mode among community college directors (36 percent). The preferred decision method among doctoral directors is the conceptual (38 percent) followed by the behavioral ( 36 percent). Baccalaureate and community college directors are the least likely to report a preference for the directive style (see table 2 ).

An analysis of variance reveals a significant difference in directors' behavioral scores (see table 3). Baccalaureate and community college directors have significantly higher behavioral scores than doctoral directors.

Further analysis reveals a significant negative correlation ( $r=-.1377)$ between behavioral style and years of administrative experience. Directors with less administrative experience are more likely to have a people-oriented behavioral style than directors with more administrative experience. Directors at private institutions tend to have significantly 
TABLE 2

MANAGERIAL DECISION STYLES \& ORIENTATIONS

(FREQUENCIES)*

\begin{tabular}{|c|c|c|c|c|}
\hline & $\begin{array}{l}\text { Doctoral } \\
(n=80)\end{array}$ & $\begin{array}{c}\text { Comprehensive } \\
(n=104)\end{array}$ & $\begin{array}{c}\text { Baccalaureate } \\
\quad(n=100)\end{array}$ & $\begin{array}{c}\text { Community } \\
(n=86)\end{array}$ \\
\hline \multicolumn{5}{|l|}{ Style } \\
\hline \multicolumn{5}{|l|}{ Directive $^{+}$} \\
\hline Very dominant & 15 & 26 & 9 & 9 \\
\hline Dominant & 11 & 11 & 12 & 14 \\
\hline Backup & 31 & 37 & 29 & 36 \\
\hline Least preferred & 23 & 30 & 43 & 27 \\
\hline \multicolumn{5}{|l|}{ Analytical $^{\ddagger}$} \\
\hline Very dominant & 12 & 17 & 15 & 10 \\
\hline Dominant & 12 & 10 & 6 & 21 \\
\hline Backup & 33 & 36 & 44 & 24 \\
\hline Least preferred & 23 & 41 & 35 & 31 \\
\hline \multicolumn{5}{|l|}{ Conceptual } \\
\hline Very dominant & 12 & 17 & 13 & 9 \\
\hline Dominant & 18 & 10 & 11 & 8 \\
\hline Backup & 22 & 35 & 41 & 30 \\
\hline Least preferred & 28 & 42 & 35 & 39 \\
\hline \multicolumn{5}{|l|}{ Behavioral $^{\S}$} \\
\hline Very dominant & 12 & 19 & 34 & 28 \\
\hline Dominant & 17 & 21 & 18 & 15 \\
\hline Backup & 22 & 40 & 33 & 27 \\
\hline Least preferred & 29 & 24 & 14 & 16 \\
\hline \multicolumn{5}{|l|}{ Orientations } \\
\hline \multicolumn{5}{|l|}{ Brain dominance } \\
\hline Left-brain dominant & 54 & 69 & 49 & 53 \\
\hline $\begin{array}{l}\text { Right-brain } \\
\text { dominant }\end{array}$ & 23 & 34 & 48 & 30 \\
\hline \multicolumn{5}{|l|}{$\begin{array}{l}\text { Action/idea } \\
\text { preference }\end{array}$} \\
\hline Action & 12 & 18 & 19 & 18 \\
\hline Idea & 67 & 86 & 79 & 67 \\
\hline
\end{tabular}

Very dominant, scores more than a full standard deviation above the mean.

Dominent, scores between half and a full standard deviation above the mean.

Backup, scores half a standard deviation above or below the mean.

Least Preferred, scores more than half the standard deviation below the mean.

${ }^{+}$The chi square value of 17.9 ( $9 \mathrm{df}$ at a $P$ value of .05$)$ is statistically significant.

₹ The chi square value of 19.34 ( $9 \mathrm{df}$ at a $P$ value of .05 ) is statistically significant.

${ }^{5}$ The chi square value of 22.97 ( $9 \mathrm{df}$ at a $P$ value of .05 ) is statistically significant.

"The chi square value of 8.81 ( $3 \mathrm{df}$ at a $P$ value of .05 ) is statistically significant. 
TABLE 3

MANAGERIAL DECISION STYLES AND ORIENTATIONS

\begin{tabular}{lccccccccc}
\hline & \multicolumn{2}{c}{$\begin{array}{c}\text { Doctoral } \\
(n=80)\end{array}$} & \multicolumn{2}{c}{$\begin{array}{c}\text { Comprehensive } \\
(n=104)\end{array}$} & \multicolumn{2}{c}{$\begin{array}{c}\text { Baccalaureate } \\
(n=100)\end{array}$} & \multicolumn{3}{c}{$\begin{array}{c}\text { Community } \\
(n=86)\end{array}$} \\
\cline { 2 - 10 } & $\mathrm{M}$ & SD & M & SD & M & SD & M & SD \\
\hline Style & & & & & & & & \\
$\quad$ Directive & 71.0 & 11.8 & 72.9 & 13.4 & 68.5 & 11.7 & 70.1 & 10.1 \\
Analytical & 85.4 & 14.2 & 83.3 & 15.0 & 82.8 & 15.1 & 84.7 & 16.1 \\
Conceptual & 84.9 & 15.1 & 82.9 & 15.2 & 82.7 & 14.8 & 79.7 & 13.7 \\
Behavioral & 57.4 & $15.3^{\mathrm{b}}$ & 60.7 & 14.6 & 65.4 & $14.3^{\mathrm{a}}$ & 64.7 & $14.8^{\mathrm{a}}$ \\
Orientations & & & & & & & & \\
$\quad$ Left-brain & 156.4 & $15.7^{\mathrm{c}}$ & 156.3 & $18.7^{\mathrm{c}}$ & 151.2 & 17.5 & 154.8 & $17.3^{\mathrm{c}}$ \\
Right-brain & 142.3 & $16.1^{\mathrm{d}}$ & 143.6 & $18.7^{\mathrm{d}}$ & 148.1 & 17.7 & 144.4 & $17.2^{\mathrm{d}}$ \\
Action & 128.4 & $18.7^{\mathrm{f}}$ & 133.6 & $17.4^{\mathrm{f}}$ & 134.0 & $17.3^{\mathrm{f}}$ & 134.8 & $15.6^{\mathrm{f}}$ \\
Idea & 170.3 & $18.4^{\mathrm{e}}$ & 166.3 & $17.3^{\mathrm{e}}$ & 165.5 & $17.5^{\mathrm{e}}$ & 164.4 & $15.9^{\mathrm{e}}$ \\
\hline
\end{tabular}

${ }^{\text {a }}$ Refers to comparisons within a row where the mean scores of group are significantly

$(P \leq .05)$ higher than the mean scores of group ${ }^{\mathrm{b}}$.

${ }^{\mathrm{cd}}$ Refers to comparisons within columns where the mean scores of group ${ }^{c}$ are significantly

$(P \leq .05)$ higher than the means of group ${ }^{d}$.

${ }^{\text {ef }}$ Refers to comparisons within columns where the mean scores of group ${ }^{\mathbf{e}}$ are significantly

$(P \leq .05)$ higher than the mean scores of group'.

higher behavioral scores than directors at public institutions. The more flexible administrative environment of private institutions, particularly small colleges, may attract behavioral style directors. Directors at smaller private colleges tend to have less administrative experience than directors at larger public institutions. As a result they may not have grown tired of "people problems."

There is a significant correlation $(r=$ .123) between age and directive style. As directors age, they may develop a more practical, factual, "here-and-now" approach. Age also correlates with leftbrain $(r=.103)$ and right-brain $(r=-.112)$ orientations. As they grow older, directors may be inclined to logical thinking and less inclined to broad thinking, creativity, and concern for people. Perhaps as directors realize that they are rewarded more for results, they are less willing to spend mental and physical energy in order to be creative or concerned for people. It could also be that as directors gain experience and administrative skills they are less dependent on their social skills.

The left-brain scores of the directors are significantly higher than their rightbrain scores (see table 3 ). With the excep- tion of baccalaureate directors, the directors (61 percent) are predominantly leftbrain oriented (see table 2). Among the baccalaureate directors, those at the more selective liberal arts colleges are more inclined to be right-brain oriented. Directors at highly selective liberal arts colleges tend to have undergraduate degrees from other highly selective colleges. The liberal arts and peoplecentered humanities influence appears to be something selective liberal arts colleges look for in their directors, perhaps to preserve their institutional uniqueness. Directors at the less selective liberal arts colleges are evenly split between the number of left-brain- and right-braindominant individuals among them. Less selective liberal arts colleges are more likely to have difficulty attracting career administrators. These directorships may be filled internally by individuals who did not actively seek the position or by individuals who are new to management. The result is perhaps a more heterogeneous collection of individuals rather than a group of self-selected career library administrators.

Overall, directors are significantly more likely to have an idea orientation than an action orientation (see table 2). 
Idea-oriented directors ( 81 percent) consistently outnumbered action-oriented directors (18 percent) by almost four to one. This ratio, with some slight deviations, is found among the directors at all types of institutions. Directors' idea orientations are significantly higher than their action orientation (see table 3 ). While no significant differences exist among directors at the different types of institutions, directors at private institutions have significantly higher action orientations than their counterparts at public institutions. No significant differences exist between men and women directors on any of the decision styles or orientations.

\section{The realization that others do not think the same way or see a situation in the same terms can be a startling experience for some individuals.}

When the decision style scores of library directors are compared with the decision style scores of others, some differences are found. An earlier study of the Decision Style Inventory was conducted for the Department of Defense among 428 individuals from nine organizations: a mix of military, aerospace, government, managerial employees, and university middle managers. ${ }^{36}$ Individuals in the Department of Defense study have significantly higher directive and analytical scores and significantly lower conceptual and behavioral scores than the library directors in this study. Using the Decision Style Model (see figure 1), it appears that library directors, despite their task (left brain) orientation, are still more people (right brain) oriented than the individuals in the Department of Defense study.

\section{COMMENTS}

In many management and leadership training programs, library managers and potential library managers are given instruments to help them identify their personality types or managerial styles. The premise behind this activity is that such self-awareness will help to make them better managers. The realization that others do not think the same way or see a situation in the same terms can be a startling experience for some individuals. For managers, seeing events and alternatives through the eyes of others is vital to preserving their managerial effectiveness. However, before attempting to understand their organization and the people in it, managers should have an understanding of themselves which permits them to see their biases, cognitive and otherwise. With this knowledge they may be able to improve their managerial effectiveness. Given the complexity of the modern organization, no one person may be able to manage an organization by depending only on his or her own abilities. While individual managers may be responsible for an organization, they need not rely solely on their own skills.

As managers, directors need to couple the effective right-brain processes (hunch, judgment, and synthesis) with the effective processes of the left-brain (articulateness, logic, and analysis). According to Mintzberg, top managers should have well-developed right-brain skills; while planners should have welldeveloped left-brain skills. Left-braindominant individuals prefer a systematic, well-ordered world and tend to show little appreciation for the more relational, holistic processes. Mintzberg concludes that the functions of both hemispheres should be respected but that abilities of one hemisphere should not be applied where the other is most effective. ${ }^{37}$

The preponderance of left-brainoriented individuals among the directors may help to explain Perry Morrison's earlier findings that supervisory qualities frequently are absent in library directors. ${ }^{38}$ Perhaps directors, with their tendency to be left-brained and ideaoriented, are more adept at planning than managing. However, if ideas and plans are to be useful, they must be effectively translated into actions. In the implementation process the involvement of other people and their skills are necessary to bring ideas to fruition.

While certain jobs and tasks require the work of one side of the brain more 
than the other, most individuals also develop a dominant side of the brain. The more this preferred hemisphere is stimulated, the better it performs. The better it performs, the more a person depends on it. Thus, if an individual tends to depend on her dominant hemisphere the less likely she is to develop the skills of her brain's other hemisphere. ${ }^{39}$

While there are preferred decision styles and a predominant orientation among directors, these styles and orientations may not be the most effective in all situations or environments. To improve their effectiveness, library managers need to develop their other decision styles and find ways to take advantage of the benefits provided by the other styles.

Directive style directors provide direction and keep things running, but they must find a way to keep people issues before them. Behavioral style directors need a "clean-up" person to establish order, write reports, provide reminders, make difficult decisions, and do other unpleasant tasks. Directors with an analytical style need people (conceptuals) who can explain their ideas to others. These directors also need people who can provide them with facts and carry out details. Conceptual style directors need people who can administer and implement regulations and see to the details. Individuals with the ability to "flesh out ideas" can be helpful to conceptual style directors. ${ }^{40}$
As managers, library directors must utilize the talents and abilities of others to be effective. Aware of their own decision styles and orientations, directors can use the strengths of others' decision modes to balance against the differences in the directors' own approaches. Library directors, like all managers, need to be aware of their strengths and preferences. But they must learn to balance their strengths and compensate for their differences if they are to make the most of their skills.

Library management and leadership programs may not provide their participants with any indication of how they compare with other library administrators. This article is an effort to fill a part of that void. Because directors with particular styles frequently are found in certain institutions, ambitious managers may wish to ask themselves how their decision styles match with those of directors at particular types of institutions. While this research shows that there are differences in decision styles among directors at different institutions, previous research also shows that directors give managerial roles different emphasis according to the type of institution that employs them. ${ }^{41}$ Aspiring library managers may wish to consider the relationship between their decision styles and the approaches frequently found at their institution or at other types of institutions where they may seek employment.

\section{REFERENCES}

1. Anthony R. Montebello, review of Managing with Style, Personnel Psychology 41 (Winter 1988): 854.

2. James L. McKenney and Peter G. W. Keen, "How Managers' Minds Work," Harvard Business Review 52(May/June 1974):79-90; John C. Henderson and Paul C. Nutt, "The Influence of Decision Style on Decision Making Behavior," Management Science 26 (Apr. 1980): 371-86.

3. Kerry A. Johnson and Marilyn D. White, "The Field Dependence/Field Independence of Information Professional Students," Library Research 3 (Winter 1981): 356.

4. J. Hill, The Educational Sciences (Bloomfield Hills, Mich.: Oakland Community College), 2, as quoted in Susan J. and Cecil L. McIntire, "A Career Counseling Model Based on Cognitive Style Assessment," Journal of Education for Librarianship 20 (Winter 1980):198-210.

5. Kerry A. Johnson and Marilyn D. White, "The Cognitive Style of Reference Librarians," $R Q 21$ (Spring 1982): 240.

6. Henderson and Nutt, "Influence of Decision Style," 372.

7. Johnson and White, "Field Dependence," 356.

8. Henderson and Nutt, "Influence of Decision Style," 372. 
9. Johnson and White, "Field Dependence," 356.

10. Henderson and Nutt, "Influence of Decision Style," 372.

11. Johnson and White, "Field Dependence," 356.

12. Ibid., 361 and 363.

13. Johnson and White, "Cognitive Style of Reference Librarians," 245.

14. Barbara L. Stein, James D. Hand, and Herman L. Totten, "Understanding Preferred Cognitive Styles-A Tool for Facilitating Better Communication," Journal of Education for Library \& Information Science 27(Summer 1986): 46 and 47.

15. David A. Kolb, "Learning Styles and Disciplinary Differences," in Arthur W. Chickering and Associates, eds., The Modern American College (San Francisco: Jossey-Bass, 1981), 232-55.

16. Jana Varlejs, "Learning Styles of Librarians and Satisfaction with Continuing Education Activities," in Esther E. Horne, ed., Continuing Education: Issues and Challenges (New York: K. G. Saur, 1985), 135; Jin M. Choi, "Learning Styles of Academic Librarians," College \& Research Libraries 50(Nov. 1989): 693-94.

17. Varlejs, "Learning Styles of Librarians," 131-39.

18. Choi, "Learning Styles of Academic Librarians," 691-99.

19. Kerry A. Johnson and Marilyn D. White, "The Cognitive Style of Information Professionals," Journal of Education for Librarianship 22(Winter 1982): 139.

20. Alan J. Rowe and James D. Boulgarides, "Decision Styles-A Perspective," Leadership \& Organization Development Journal 4(1983): 3.

21. Ibid., 3-4.

22. Ibid., 5 .

23. Ibid.

24. Rowe and Boulgarides, "Decision Styles," 5-6; Alan J. Rowe and Richard D. Mason, Managing with Style: A Guide to Understanding, Assessing, and Improving Decision Making (San Francisco: Jossey-Bass, 1987), 4, 45-46.

25. Rowe and Boulgarides, "Decision Styles," 5-6; Rowe and Mason, Managing with Style, $4,46-48$.

26. Rowe and Boulgarides, "Decision Styles," 5-6; Rowe and Mason, Managing with Style, $4,48-49$.

27. Rowe and Boulgarides, "Decision Styles," 5-6; Rowe and Mason, Managing with Style, 4, 49-50.

28. Rowe and Mason, Managing with Style, 157.

29. Ibid., 193-94.

30. Ann McGee-Cooper, You Don't Have to Come Home from Work Exhausted! (Dallas, Tex.: Bowen \& Rogers, 1990), 125-26.

31. Henry Mintzberg, "Planning on the Left Side and Managing on the Right," Harvard Business Review 54 (July/Aug. 1976): 52.

32. Rowe and Mason, Managing with Style, 128; McGee-Cooper, You Don't Have to Come Home from Work Exhausted, 133-34.

33. Ibid.

34. Rowe and Mason, Managing with Style, 128.

35. "The Annual Report on the Economic Status of the Profession 1990-1991" [Special issue], ACADEME: Bulletin of the American Association of University Professors 77(Mar.Apr. 1991): 2.

36. Rowe \& Mason. Managing with Style, 190-91.

37. Mintzberg, "Planning on the Left Side," 50, 53, 57.

38. Perry D. Morrison, The Career of the Academic Librarian (Chicago: ALA, 1969), 83

39. McGee-Cooper, You Don't Have to Come Home from Work Exhausted, 127.

40. Rowe and Mason, Managing with Style, 86-87.

41. Terrence F. Mech, "Academic Library Directors: A Managerial Role Profile," College \& Research Libraries 51(Sept. 1990): 415-28. 


\section{New Books for the College Library from Greenwood Press}

\section{DICTIONARY OF AMERICAN \\ RELIGIOUS BIOGRAPHY}

Second Edition, Revised and Enlarged

by Henry Warner Bowden

The first edition of this award-winning reference, published in 1977 , contained 425 biographical profiles of the most significant American religious leaders. Bowden has added profiles for 125 additional figures, and the earlier sketches have been revised and updated. Appendices categorize the figures by religious denomination and place of birth. The dictionary contains entries for individuals who died before July 1, 1992, and reflects America's cultural and religious diversity.

Greenwood Press. 1993. 720 pages. 0-313-27825-3.\$75.00

CRITICAL APPROACHES TO INFORMATION TECHNOLOGY IN LIBRARIANSHIP

Foundations and Applications

Edited by John Buschman

This book challenges the uncritical acceptance of changes caused by constant developments in information technology. The first part of the book explores the fundamental critical issues at the heart of technology in the library. The second part of the volume looks more closely at issues related to the application of technology in librarianship. A selected bibliography concludes the work.

Greenwood Press. 1993. 248 pages. 0-313-28415-6. $\$ 55.00$

\section{PLANNING SECOND GENERATION AUTOMATED LIBRARY SYSTEMS}

By Edwin M. Cortez and Tom Smorch

This guide focuses on the implementation and management of second-generation automated library systems. It advances knowledge of the field by describing the "migration path" of library automated systems. Specifically, the book is intended to give practical directions in procuring a replacement library automated system. It discusses state-of-the-art technology such as scanning and imaging devices, and provides descriptions and analyses of telecommunications and networking technology and issues.

Greenwood Press. 1993. 248 pages. 0-313-28361-3. \$47.95

\section{STRATEGIC MANAGEMENT FOR ACADEMIC LIBRARIES \\ A Handbook}

By Robert M. Hayes

This professional reference for academic librarians provides detailed guidance for the strategic management of academic libraries. The first part of the work overviews definitions and discusses the issues and objectives central to strategic library management. The second part contains chapters on the academic and external contexts within which the library functions, and looks at the impact of those contexts on the strategic management plan. The third part provides

\section{CIDCGREENWOOD PUBLISHING GROUP}

detailed information on technical tools and procedures by which strategic management can be accomplished. Greenwood Press. 1993. 240 pages. 0-313-28111-4. $\$ 55.00$

\section{NEWS MEDIA LIBRARIES}

\section{A Management Handbook}

Edited by Barbara P. Semonche

Semonche provides a wealth of information on news libraries and the managerial concerns of news librarians. The volume is organized in several broad sections devoted to the history and mission of news libraries, managerial issues and approaches, news libraries and computerassisted journalism, special concerns of news libraries, and profiles of particular types of news libraries. The volume concludes with a more extensive glossary and an annotated bibliography of books and articles published between 1985 and 1991.

Greenwood Press. 1993. 680 pages. 0-313-27946-2. $\$ 75.00$

\section{AMERICAN POLITICAL SCIENTISTS A Dictionary}

Edited by Glenn $\mathrm{H}$. Utter and Charles Lockhart

This dictionary offers the only comprehensive collection of profiles of political scientists who have made significant contributions to the intellectual development of American political science from its beginnings in the late nineteenth century to the present. Entries by 111 experts are arranged alphabetically and focus on the main ideas and publications of each political scientist. Appendices and extensive crossreferences and a general index make this landmark major reference easily accessible.

Greenwood Press. 1993. 400 pages. 0-313-27849-0. $\$ 85.00$

\section{FORTHCOMING}

REACHING A MULTICULTURAL STUDENT COMMUNITY

A Handbook for Academic Librarians

By Karen E. Downing, Barbara MacAdam, Darlene P. Nichols

Changing student demographics demand that colleges and universities meet the special needs of a new population, and libraries will play an increasingly important role in facing these challenges of the future. This professional reference is intended for academic librarians interested in establishing peer outreach programs for minority students. The volume includes an overview of the unique challenges facing academic institutions and libraries today in serving a diverse student population, suggestions on working effectively in the current academic environment, and practical guidelines for specific program design, implementation, and evaluation.

Greenwood Press. Available October 1993. 0-313-27912-8. \$50.00 Est. 


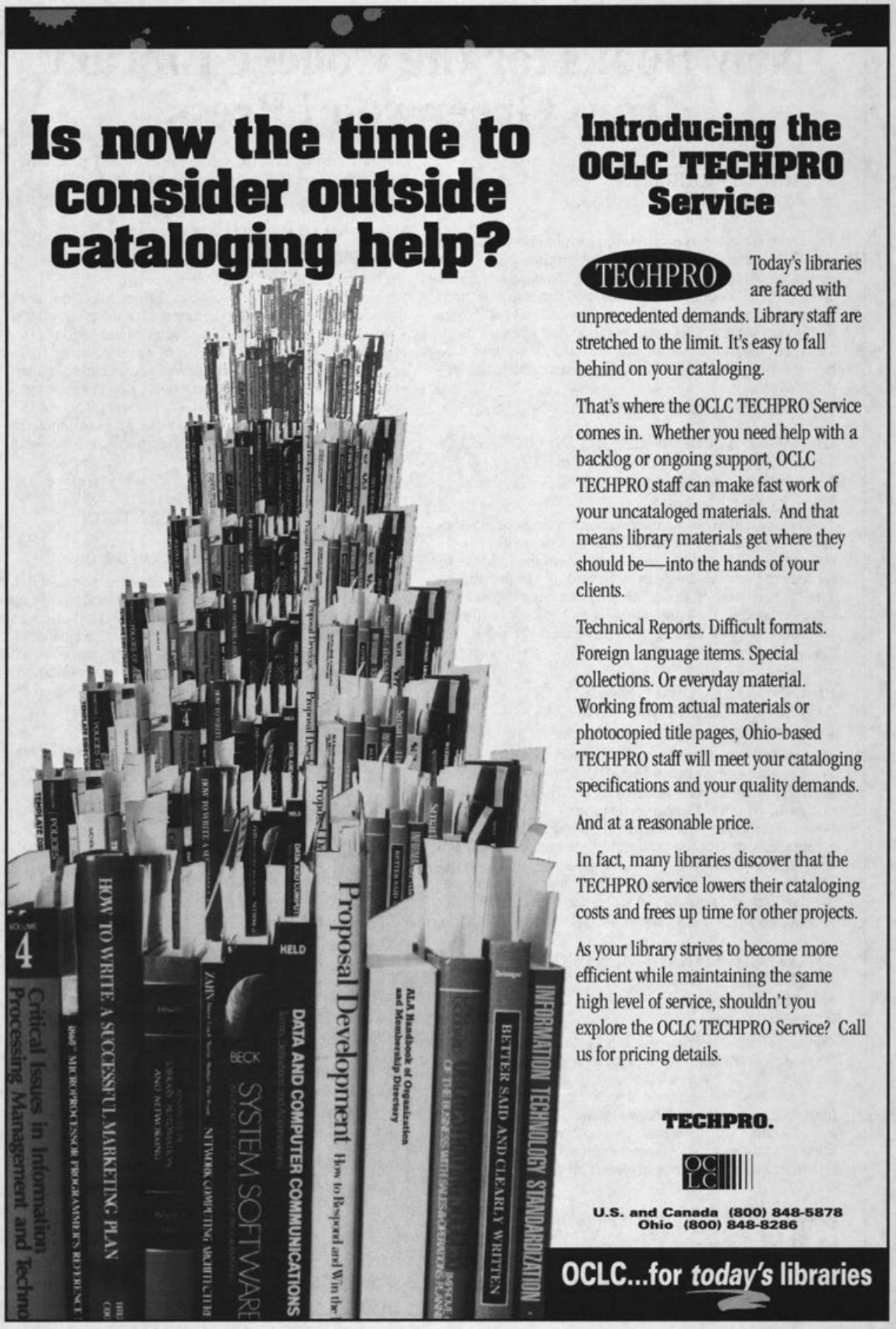

